composition in relation to fall in blood pressure with a note on measurement of angiotensin II during converting enzyme inhibition. Br Heart $\mathcal{F}$ $1980 ; 44: 290-6$.

16 Wright BM, Dore CF. A random-zero sphygmomanometer. Lancet $1970 ; 1: 337-8$

${ }^{17}$ Davies DL, Robertson JWK. Simultaneous measurements of total exchangeable potassium and sodium using ${ }^{43} \mathrm{~K}$ and ${ }^{24} \mathrm{Na}$. Metabolism 1973;22:133-7.

18 Boddy K, King PC, Tothill P, Strong JA. Measurement of total body potassium with a shadow shield whole-body counter: calibration and errors. Phys Med Biol 1971;16:275-82.

19 Rasmussen S, Nielsen MD, Giese J. Captopril combined with thiazide lowers renin substrate concentration: implications for methodology in renin assays. Clin $S_{c i} 1981 ; 60: 591-3$.

${ }^{20}$ Hodsman GP, Isles CG, Murray GD, Usherwood TP, Webb DJ, Robertson JIS. Factors related to first dose hypotensive effect of captopril: prediction and treatment. $\mathrm{Br}$ Med f 1983;286:832-4.

${ }^{21}$ Brown JJ, Casals-Stenzel J, Cumming AMM, et al. Angiotensin II, aldosterone and arterial pressure: a quantitative approach. Hypertension 1979;1:159-79.

22 Bean BL, Brown JJ, Casals-Stenzel J, et al. The relation of arterial pressure and plasma angiotensin II in the conscious dog. A change produced by prolonged infusion of angiotensin II. Circ Res 1979;44: 452-8.

${ }^{23}$ Atkinson AB, Brown JJ, Fraser R, et al. Antagonists and inhibitors of the renin-angiotensin-aldosterone system in the treatment of hyper- tension. In: Robertson JIS, Pickering Sir George, eds. The therapeutics of hypertension. London: Academic Press, 1980:29-61. (Royal Society of Medicine International Congress \& Symposium Series No 26.)

${ }^{24}$ Hollenberg NK. Renal response to angiotensin-converting enzyme inhibition. Am 7 Cardiol 1982;49:1425-9.

${ }^{25}$ Farrow PR, Wilkinson R. Reversible renal failure during treatment with captopril. $\mathrm{Br} \mathrm{Med} \mathcal{F} 1979 ; \mathrm{i}: 1680$.

26 Hrick De, Browning PJ, Kopelman R, Goorno WE, Madias NE, Dzau VJ. Captopril induced functional renal insufficiency in patients with bilateral renal-artery stenoses or renal artery stenosis in a solitary kidney. $N$ Engl F Med 1983;308:373-6.

${ }^{27}$ Silas JH, Klenka Z, Solomon SA, Bone JM. Captopril induced reversible renal failure: a marker of renal artery stenosis affecting a solitary kidney. Br Med F 1983; : 1702-3.

28 Anderson WP, Korner PI, Johnston CI. Acute angiotensin II mediated restoration of distal renal artery pressure in renal artery stenosis and its relationship to the development of sustained "one-kidney" hypertension in conscious dogs. Hypertension 1979;1:292-8.

29 Aldigier J-C, Plouin P-F, Guyene TT, Thibonnier M, Corvol P, Menard J. Comparison of hormonal and renal effects of captopril in severe essential and renovascular hypertension. Am $\mathcal{F}$ Cardiol 1982;49:1447-52.

${ }^{30}$ Hollenberg $N$. Renal artery thrombosis caused by antihypertensive treatment. Br Med f 1983;286:893.

(Accepted 22 August 1983)

\title{
Psychiatric morbidity in patients with alcoholic liver disease
}

\author{
ISAAC EWUSI-MENSAH, J B SAUNDERS, A D WODAK, R M MURRAY, ROGER WILLIAMS
}

\begin{abstract}
Seventy one patients with alcoholic liver disease and an equal number with non-alcoholic liver disease were interviewed using the schedule for affective disorders and schizophrenia. Forty seven $(66 \%)$ of the group with alcoholic liver disease had or had had psychiatric illnesses compared with $23(32 \%)$ of the control group (p<0.001). Affective disorder, particularly major depression, neurotic disorders, and antisocial personality, were all more common among the patients with alcoholic liver disease than the controls. No patient had schizophrenia or other forms of psychosis. Among the patients with alcoholic liver disease 11 men (24\%) and 14 women $(54 \%)$ had an affective or a neurotic disorder that had antedated their heavy drinking, and $30(77 \%)$ of those who had had such a problem at any time had symptoms at the time of interview.

Abstinence from alcohol is essential for patients with severe alcoholic liver disease. In view of the high prevalence of psychiatric disorders in these patients psychiatric assessment is important to increase the patients' likelihood of complying with such advice.
\end{abstract}

\footnotetext{
Liver Unit, King's College Hospital and Medical School, and Institute of Psychiatry, London SE5

ISAAC EWUSI-MENSAH, MRCPSYCH, honorary senior registrar

J B SAUNDERS, MRCP, lecturer

A D WODAK, FRACP, honorary senior registrar

R M MURRAY, MD, MRCPSYCH, dean, Institute of Psychiatry

ROGER WILLIAMS, MD, FRCP, consultant physician and director of liver unit

Correspondence to: Dr J B Saunders.
}

\section{Introduction}

Although individual susceptibility to the hepatotoxic effects of alcohol varies greatly, both alcoholic hepatitis and alcoholic cirrhosis usually take many years to develop. ${ }^{12}$ The average cumulative alcohol intake reported by patients in a recent study was nearly $800 \mathrm{~kg}$, an amount equivalent to $120 \mathrm{~g}$ alcohol (eight pints of beer or half a bottle of spirits) daily for 20 years. ${ }^{3}$ Many factors contribute to the development and perpetuation of excessive drinking, including social and cultural influences, family background, personality, and psychiatric disturbance. The association between alcoholism and psychiatric morbidity is well established, ${ }^{4-7}$ and in many cases alcohol abuse seems to be symptomatic of an underlying psychiatric illness.

Most studies linking alcoholism and psychiatric illness have been conducted among patients presenting to psychiatric units for treatment of alcohol dependence and the attendant social and psychological problems. The prevalence of psychiatric illness in patients presenting with physical complications of excessive drinking has not been systematically investigated. The impression has been that overt psychiatric disorder is uncommon, and in a recent study of 100 patients with alcoholic liver disease only nine were thought to require psychiatric help. ${ }^{8}$ This relative rarity of psychiatric illness accords with suggestions that many patients who develop alcoholic liver disease are only heavy "social" drinkers, and in a recent study severe alcohol dependence was found to be uncommon."

The aim of the present study was to assess the prevalence and clinical nature of psychiatric morbidity in patients presenting for management of alcoholic liver disease. We also studied a group of patients with non-alcoholic liver disease who were similar with respect to age, sex, social class, and severity of disease.

\section{Patients and methods}

Over 18 months we interviewed 142 patients within a week after admission to hospital. Seventy one (45 men and 26 women) had 
alcoholic liver disease as judged by a history of alcohol consumption of over $80 \mathrm{~g} /$ day for five years or more and compatible liver biopsy appearances, and 71 (45 men, 26 women) had chronic non-alcoholic liver disease proved by biopsy. We interviewed only patients aged 20-60 and excluded those who in our clinical judgment were too ill to withstand a rigorous psychiatric interview, had signs of hepatic encephalopathy, or had a history of head injury with prolonged coma or of coma from drug overdose. The patients interviewed represented $72 \%$ of those who fulfilled our criteria for inclusion; the rest, who were similar in other respects, were not available for interview because they were undergoing diagnostic procedures. All patients gave

TABLE I-Overall prevalence of psychiatric illness (figures are numbers $(\%)$ of patients)

\begin{tabular}{cccc}
\hline & Alcoholic liver disease & Non-alcoholic liver disease & $\mathrm{p}$ \\
\hline Men & $27(60)$ & $11(24)$ & $<0.001$ \\
Women & $20(77)$ & $12(46)$ & $<0.05$ \\
\hline Total & $47(66)$ & $23(32)$ & $<0.001$ \\
\hline
\end{tabular}

order, unspecified functional psychosis, drug abuse, and alcoholism. By gathering information on the chronology of development of symptoms we determined, in the alcoholic patients, whether the psychiatric disorder had antedated their heavy drinking or vice versa. ${ }^{14}$ Marital state and occupation were noted.

The $\chi^{2}$ test, with Yates's correction when necessary, was used to test for significance.

\section{Results}

Psychiatric disorders were significantly more common in the patients with alcoholic liver disease $(66 \%)$ than in the control group $(32 \%$; table I). Overall, the commonest conditions encountered were affective disorder, neuroses, and antisocial personality; suicidal behaviour and drug abuse were much less common, and no patient was diagnosed as having schizophrenia, schizoaffective disorder, or unspecified functional psychosis (table II). Fifteen $(21 \%)$ of the group with alcoholic liver disease and five $(7 \%)$ of the controls had been referred for treatment of a psychiatric disorder (other than alcoholism) at some stage in their life.

TABLE II-Prevalence of certain psychiatric disorders in patients with alcoholic compared with non-ulcoholic liver disease (figures are numbers ( $\%$ ) of patients)

\begin{tabular}{|c|c|c|c|c|c|c|}
\hline & \multicolumn{3}{|c|}{ Men } & \multicolumn{3}{|c|}{ Women } \\
\hline & $\begin{array}{l}\text { Alcoholic liver disease } \\
\qquad(\mathrm{n}=45)\end{array}$ & $\begin{array}{l}\text { Non-alcoholic liver disease } \\
\qquad(\mathrm{n}=45)\end{array}$ & p & $\begin{array}{l}\text { Alcoholic liver disease } \\
\qquad(\mathrm{n}=26)\end{array}$ & $\begin{array}{l}\text { Non-alcoholic liver disease } \\
\qquad(\mathrm{n}=26)\end{array}$ & $\mathrm{p}$ \\
\hline $\begin{array}{l}\text { Affective disorders } \\
\text { Neuroses } \\
\text { Antisocial personality } \\
\text { Suicidal behaviour } \\
\text { Drug abuse }\end{array}$ & $\begin{array}{r}18(40) \\
7(16) \\
15(33) \\
3(7) \\
6(13)\end{array}$ & $\begin{array}{l}6(13) \\
4(9) \\
6(13) \\
1 \quad(2) \\
4 \quad(9)\end{array}$ & $\begin{array}{l}<0.01 \\
\text { NS } \\
<0.02 \\
\text { NS } \\
\text { NS }\end{array}$ & $\begin{array}{l}16(62) \\
12(46) \\
2(8) \\
3(12) \\
0\end{array}$ & $\begin{aligned} 10 & (38) \\
4 & (15) \\
0 & \\
2 & (8) \\
1 & (4)\end{aligned}$ & $\begin{array}{l}\text { NS } \\
<0.05 \\
\text { NS } \\
\text { NS } \\
\text { NS }\end{array}$ \\
\hline
\end{tabular}

TABLE III-Evolution of psychiatric illness in patients with alcoholic liver disease (figures are numbers (\%) of patients)

\begin{tabular}{|c|c|c|c|c|c|}
\hline & $\begin{array}{l}\text { Prevalence } \\
\text { of disorder }\end{array}$ & $\begin{array}{c}\text { Antedated } \\
\text { heavy drinking }\end{array}$ & $\begin{array}{c}\text { Followed } \\
\text { heavy drinking }\end{array}$ & $\begin{array}{c}\text { Present in six months } \\
\text { before admission }\end{array}$ & $\begin{array}{c}\text { Present at time of } \\
\text { interview }\end{array}$ \\
\hline \multicolumn{6}{|c|}{$\operatorname{Men}(n=45)$} \\
\hline $\begin{array}{l}\text { Any psychopathology } \\
\text { Affective disorders } \\
\text { Neurotic disorders }\end{array}$ & $\begin{array}{r}27(60) \\
18(40) \\
7(16)\end{array}$ & $\begin{array}{r}21(47) \\
10(22) \\
5(11)\end{array}$ & $\begin{array}{l}6(13) \\
8(18) \\
2(4)\end{array}$ & $\begin{array}{r}24(53) \\
16(36) \\
7(16)\end{array}$ & $\begin{array}{r}21(47) \\
13(29) \\
6(13)\end{array}$ \\
\hline \multicolumn{6}{|c|}{ Women $(n=26)$} \\
\hline $\begin{array}{l}\text { Any psychopathology } \\
\text { Affective disorders } \\
\text { Neurotic disorders }\end{array}$ & $\begin{array}{l}20(77) \\
16(62) \\
12(46)\end{array}$ & $\begin{array}{r}12(46) \\
12(46) \\
6(23)\end{array}$ & $\begin{array}{l}8(31) \\
4(15) \\
6(23)\end{array}$ & $\begin{array}{r}15(58) \\
9(35) \\
11(42)\end{array}$ & $\begin{array}{r}12(46) \\
7(27) \\
9(35)\end{array}$ \\
\hline
\end{tabular}

informed consent before being included in the study; none refused to participate.

Of those with alcoholic liver disease, $48(68 \%)$ had cirrhosis and the remaining 23 had alcoholic hepatitis or a fatty and fibrotic liver. The mean age of the men was 42.8 (SD 10.8) years and of the women $44.8(9.8)$ years. Of the group with non-alcoholic liver disease, $25(35 \%)$ had chronic active hepatitis, $17(24 \%)$ had primary biliary cirrhosis, and the rest had various other types of chronic liver disease including haemochromatosis and sclerosing cholangitis; $43(61 \%)$ had cirrhosis. None had a mean daily alcohol intake exceeding $40 \mathrm{~g}$. The mean age of the men was 39.3 (12.5) years and of the women $39 \cdot 2(13 \cdot 9)$ years; these ages were not significantly different from those in the group with alcoholic liver disease. Most patients had been referred for investigation and management of jaundice, ascites, or variceal haemorrhage; five with alcoholic liver disease had been referred by psychiatrists for investigation of abnormal results of liver function tests.

Assessment of psychiatric morbidity-Psychiatric morbidity was assessed by a psychiatrist using the schedule for affective disorders and schizophrenia (life time version) questionnaire. ${ }^{10}$ This is a structured interview questionnaire that takes about an hour to administer and rates past as well as current psychiatric conditions. ${ }^{1011}$ It yields valid and reproducible estimates of lifetime experience of most psychiatric disorders. ${ }^{12}{ }^{13}$ On the basis of information obtained with the questionnaire the presence of psychiatric disorder was then determined according to the research diagnostic criteria. ${ }^{11}$ The diagnostic categories used were: affective disorder, neuroses, antisocial personality, suicidal behaviour, schizophrenia, schizoaffective dis-
Both affective disorder and neuroses were more common in patients with alcoholic as compared with non-alcoholic liver disease (table II) and tended to be more severe in those with alcoholic liver disease. Thus of the 18 men with alcoholic liver disease with affective disorder, seven had suffered a major depressive illness, four had had a bipolar illness, and the rest had minor or intermittent depression. By contrast, none of the control patients had experienced major depression, one had a bipolar disorder, and five had minor depression. Affective disorder was generally more common among women than men, but there was no significant difference between the women with alcoholic liver disease and those in the control group. Nevertheless, eight women with alcoholic liver disease had suffered major depression compared with only three in the control group. Two women with alcoholic liver disease, had had a bipolar illness and six minor or intermittent depression; seven control patients had experienced minor depression. The affective disorder had antedated the period of excessive drinking in $10(22 \%)$ of the men with alcoholic liver disease and in $12(46 \%)$ of the women (table III). In most patients with affective disorder symptoms had been present within six months before admission, and in 20 ( $28 \%$ of the whole group) they were present at the time of interview.

Of the seven men with alcoholic liver disease with neurotic disorders, two had panic disorder, two phobic disorder, and three generalised anxiety, compared with one control patient with panic disorder and three with generalised anxiety. Neurotic disorders were significantly more common in women in both groups and especially in the women with alcoholic liver disease, of whom three had panic disorder, six phobic disorder, and three a generalised anxiety state, 
compared with one control patient with panic disorder and three with phobic anxiety. In five $\left(11^{\circ}\right)$ of the men and six $(23 \%)$ of the women with alcoholic liver disease the neurotic disorder had preceded their heavy drinking: once present symptoms tended to persist (table III).

Antisocial personality was significantly more common in men with alcoholic liver disease $\left(33^{\circ}\right)$ ) than in the corresponding control group $(13 \%$; table II). It was rare in women, being diagnosed in only two with alcoholic liver disease. By definition, features of this had occurred in childhood and therefore before the onset of heavy drinking.

\section{Discussion}

By using a well validated psychiatric diagnostic schedule we found that psychiatric disorders, particularly depression, neuroses, and antisocial personality, are more common, and more severe, in patients with alcohol induced liver disease than in patients with other forms of chronic liver disease of comparable severity. Although in some cases it was not easy to define the relative onset of the psychiatric illness and the alcohol problem, by careful elucidation of the chronological development of the psychiatric disorder in relation to the drinking history we found that $24 \%$ of the men and $54 \%$ of the women with alcoholic liver disease had an affective or a neurotic disorder that had preceded their heavy drinking. In all, 33 patients $(46 \%)$ had an antecedent psychiatric problem; in $14(20 \%)$ the psychiatric illness appeared to be secondary either to the patient's excessive drinking habits or to physical ill health because of the development of alcoholic liver disease. Twenty four patients $(34 \%)$ had no psychopathology. Comparison with a control group of patients with non-alcoholic liver disease is important because $20-30 \%$ of patients admitted to general medical wards ${ }^{15}{ }^{16}$ and, in a recent study, ${ }^{17} 35 \%$ of patients with acute myocardial infarction have evidence of preexisting or secondary psychiatric illness.

The association of alcoholism with several forms of psychopathology is well recognised. Previous studies, however, have been carried out among patients presenting to psychiatric units for treatment of alcoholism, usually because they have become severely dependent on alcohol and have developed the attendant social and psychological problems. We recently showed that patients with chronic liver disease induced by alcohol differ in many respects from such patients: they are usually older and only mildly dependent on alcohol, if at all. ${ }^{9}$ Furthermore, they have rarely received formal treatment for a drinking problem (J B Saunders, A D Wodak, R Williams, unpublished observations). A high prevalence of psychiatric problems in such patients might not be expected.

The results of the present study indicate that most patients with alcoholic liver disease do indeed have psychiatric disorders; these are often covert and are not recognised by the medical staff, who tend to concentrate on managing the patients' physical complaints. Most patients present with haematemesis, jaundice, or ascites. ${ }^{18}$ These dramatic forms of presentation naturally overshadow any psychological factors underlying the illness, and consequently little attention is paid to assessing these factors and determining how they should be managed.

There is a particularly close relation between heavy drinking and affective disorder.1920 Schuckit and Winokur emphasised the importance of diagnosing primary affective disorder in patients presenting with alcohol problems: a three year follow up study of women with a primary affective disorder and secondary alcoholism who were treated with antidepressants showed that they had a better prognosis than patients with primary alcoholism. ${ }^{21}$ Neurotic disorders are also commonly associated with alcoholism, and regardless of whether the neurosis is primary or secondary, it should be identified so that appropriate treatment may be started. The prognosis of patients with antisocial personality is known to be poor. ${ }^{22}{ }^{23}$

Despite the high prevalence of psychiatric disorders in patients with alcoholic liver disease few are referred to psychiatrists. Many patients continue to drink after discharge from hospital, ${ }^{18}$ and probably this is in part because of untreated psychiatric illness. Those concerned with the management of patients with alcoholic liver disease need to be aware of the high prevalence of psychiatric illness. Ideally all such patients should be assessed by a psychiatrist during their admission. As this might not be practical in many hospitals an alternative approach would be to use a self administered questionnaire such as the general health questionnaire to screen for those requiring psychiatric intervention. We are currently exploring this possibility.

This work was supported in part by grants from the Department of Health and Social Security and the Brewers' Society, London.

\section{References}

1 Wilkinson P, Santamaria JN, Rankin JG. Epidemiology of alcoholic cirrhosis. Australasian Annals of Medicine 1969;18:222-6.

${ }^{2}$ Lelbach WK. Epidemiology of alcoholic liver disease. In: Popper $\mathrm{H}$ Schaffner F, eds. Progress in liver diseases. Vol V. New York: Grune and Stratton, 1976:494-515.

${ }^{3}$ Saunders JB, Wodak AD, Haines A, et al. Accelerated development of alcoholic cirrhosis in patients with HLA-B8. Lancet 1983;i:1381-4.

4 Amark C. A study in alcoholism. Acta Psychiatrica et Neurologica Scandinavica Supplement 1951;70:1-283.

5 Wood HP, Duffy EL. Psychological factors in alcoholic women. Am $\mathcal{F}$ Psychiatry 1966;123:341-5.

${ }^{6}$ Beckman LJ. Women alcoholics: a review of social and psychological studies. F Stud Alcohol $1975 ; 36: 797-824$

${ }^{7}$ Weissman MR, Myers JK. Clinical depression in alcoholism. $A m \mathcal{F}$ Psychiatry 1980;137:372-3.

${ }^{8}$ Morgan MY, Sherlock S. Sex-related differences among 100 patients with alcoholic liver disease. $\mathrm{Br}$ Med 7 1977;i :939-41.

${ }^{9}$ Wodak AD, Saunders JB, Ewusi-Mensah I, Davis M, Williams $R$ Severity of alcohol dependence in patients with alcoholic liver disease. Br Med F 1983;287:1418-20.

${ }^{10}$ Endicott J, Spitzer RL. A diagnostic interview. The schedule for affective disorders and schizophrenia. Arch Gen Psychiatry 1978;35:837-44.

11 Spitzer RL, Endicott J, Robins E. Research diagnostic criteria. Arch Gen Psychiatry 1978;35:773-82.

12 Mazure C, Gershon ES. Blindness and reliability in lifetime psychiatric diagnosis. Arch Gen Psychiatry 1979;36:521-5.

13 Andreasen NC, Grove WM, Shapiro RW, Keller MB, Hirchfield RMA, McDonald-Scott P. Reliability of lifetime diagnosis. Arch Gen Psychiatry $1981 ; 38: 400-5$.

14 Schuckit MA. Alcoholism and secondary depression. Am $\mathcal{F}$ Psychiatry 1983;140:711-4.

15 Maguire GP, Julien DI, Hawton KE, Bancroft JHJ. Psychiatric morbidity and referral on two general medical wards. Br Med 7 1974; i :268-70.

${ }^{16} \mathrm{Knights}$ EB, Folstein MF. Unsuspected emotional and cognitive disturbance in medical patients. Ann Intern Med 1977;87:273-4.

17 Lloyd GG, Cawley RH. Psychiatric morbidity in men one week after first acute myocardial infarction. $\mathrm{Br}$ Med f 1978;ii:1453-4.

18 Saunders JB, Walters JRF, Davies P, Paton A. A 20 -year prospective study of cirrhosis. Br Med $\mathcal{F} 1981 ; 282: 263-6$.

${ }^{19}$ Morrison JR. Bipolar affective disorder and alcoholism. Am $\mathcal{F}$ Psychiatry $1974 ; 131: 1130-4$

20 Winokur G, Clayton P. Family history studies. II. Sex differences in alcoholism in primary affective illness. $B r \mathcal{F}$ Psychiatry 1967;113: 973-9.

${ }^{21}$ Schuckit MA, Winokur G. A short term follow up of women alcoholics. Diseases of the Nervous System 1972;33:672-8.

22 Winokur G, Reich T, Rimmer J, Pitts FN. Alcoholism. III. Diagnosis and familial psychiatric illness in 259 alcoholic probands. Arch Gen Psychiatry 1970;23:104-11.

${ }^{23}$ Schuckit MA. Alcoholism and sociopathy-diagnostic confusion. Quarterly Fournal of Studies on Alcohol 1973;34:157-64.

(Accepted 24 August 1983)

THE STOMACH, AND ITS INFIRMITIES-Infirmities of the stomach usually proceed from surfeiting. Let such as have weak stomachs, avoid all sweet things, as honey, sugar, and the like; milk, cheese and all fat meats: let him not eat till he is hungry, nor drink before he is dry; let him avoid anger, sadness, much travel, and all fryed meats: let him not vomit by any means, nor eat when he is hot. For moisture of the Stomach-Take a drachm of Galanga, in powder, every morning in a draught of that Wine you like best. For heat of the Stomach-Swallow four or five grains of Mastich every night going to bed. (Nicholas Culpeper (1616-54) The Complete Herbal, 1850.) 